\title{
Cowling, Camillia \\ Conceiving Freedom: \\ Women of Color, Gender, and the Abolition \\ of Slavery in Havana and Rio de Janeiro
}

Ynaê Lopes dos Santos*

Chapel Hill: The University of North Carolina Press, 2013. 344p.

Ramona Oliva e Josepha Gonçalves de Moraes poderiam ter sido heroínas dos folhetins e romances que enchiam de angústia e compaixão a alma dos leitores do final do século XIX. Negras, cativas ou ex-escravas, essas mulheres foram em busca do aparato legal disponível em Havana e no Rio de Janeiro, respectivamente, e fizeram de sua condição e do afeto materno as principais armas na longa luta pela liberdade de seus filhos na década de 1880. Todavia, a saga dessas mulheres não era fruto da vertente novelesca do século XIX e tampouco foi fartamente estampada nos jornais da época. Para conhecer e nos contar essas histórias, Camillia Cowling fez uma intensa pesquisa em arquivos do Brasil, de Cuba, Espanha e Grã-Bretanha, tecendo com o cuidado que o tema demanda a trajetória de mulheres negras - libertas e escravas - que entre o fim da década de 1860 e a abolição da escravidão em Cuba (1886) e no Brasil (1888) utilizaram o aparato legal disponível nas duas maiores cidades escravistas das Américas para lutar pela liberdade de seus filhos e filhas.

A fim de dar corpo a uma história que muitas vezes é apresentada como estatística, a autora examinou uma série de documentos legais produzidos a partir da década de 1860 para compreender os caminhos traçados por algumas mulheres em busca da liberdade. Em pleno diálogo com as importantes bibliografias sobre gênero e escravidão produzidas nos últimos anos, Camillia Cowling nos brinda com um livro sobre mulheres negras, maternidade, escravidão e liberdade, demonstrando como as histórias de Ramona, Josepha e outras tantas libertas e escravas, longe de serem anedotas do sistema escravista, podem ser tomadas como portas de entrada para a compreensão mais fina da dinâmica da escravidão no Novo Mundo nas duas últimas localidades em que essa instituição perdurou.

* Escola Superior de Ciências Sociais CPDOC-FGV. Rio de Janeiro, RJ, Brasil. ynae.santos@fgv.br ${ }^{1}$ 
A complexidade do tema abordado e o ineditismo das articulações entre história da escravidão nas Américas, abolicionismo, dinâmica urbana, agência de mulheres negras, maternidade e processos jurídicos se expressam na forma como a autora organizou sua obra.

Na primeira parte de seu livro, Camillia Cowling trabalhou com a relação entre escravidão e espaço urbano naquelas que foram as maiores cidades escravistas das Américas, Havana e Rio de Janeiro. Analisando as dinâmicas de funcionamento da escravidão urbana, a autora sublinhou que as cidades não devem ser tomadas como mero pano de fundo dos estudos sobre escravismo nas Américas, e assim construiu uma narrativa que corrobora boa parte do que a historiografia aponta: a força que a escravidão exerceu sobre o funcionamento dessas urbes. Tal força poderia agir tanto nas especificidades geradas em torno das atividades executadas pelos escravos urbanos - sobretudo no que tange à maior autonomia dos escravos de ganho -, como nos sentidos e usos que essas cidades passaram a ter para a população escrava e liberta, a qual muitas vezes fez do emaranhado espaço citadino esconderijos e refúgios de liberdade. $\mathrm{O}$ engajamento jurídico das mulheres escravas e libertas frente às políticas graduais de abolição de cada uma dessas cidades é, pois, apresentado como mais uma característica da complexa dinâmica que permeou a escravidão urbana no Rio de Janeiro e em Havana.

A escolha pelas duas cidades não foi aleatória, muito menos pautada apenas por índices demográficos. Ainda que a autora tenha anunciado trabalhar com base na metodologia da micro-história, a abordagem comparativa que estrutura sua análise se pauta no diálogo com perspectivas mais sistêmicas da escravidão das Américas, principalmente com as balizas que norteiam a tese da segunda escravidão (Tomich, 2011). Como vem sendo defendido por uma crescente vertente historiográfica, a paridade entre Havana e Rio de Janeiro - pressuposto fundamental da análise de Camillia Cowling - seria resultado de uma série de escolhas semelhantes feitas pelas elites de Cuba e do Brasil em prol da manutenção da escravidão desde o último quartel do século XVIII até meados do século XIX, mesmo em face do crescente movimento abolicionista. Tal política pró-escravista (que também foi levada a cabo pelos Estados Unidos) teria permitido que a escravidão moderna se adequasse à expansão capitalista, criando assim um chão comum na dinâmica da escravidão nessas duas localidades, inclusive no que concerne às possibilidades legais que os escravos acionaram para lutar pela liberdade - possibilidades essas que se ampliaram após a abolição da escravidão nos Estados Unidos. Não por acaso, as capitais de Cuba e do Brasil transformaram-se em espaços privilegiados para que mulheres negras, apropriando-se do próprio conceito de maternidade e ressignificando-o, utilizassem as leis abolicionistas reformistas, nomeadamente a Lei 
Moret de Cuba (1870) e a Lei do Ventre Livre do Brasil (1871), para resgatar seus filhos do cativeiro.

Os caminhos percorridos pelas mulheres escravas e libertas e as muitas maneiras por meio das quais elas conceberam a liberdade (de seus filhos e delas próprias) passam a ser examinados pormenorizadamente a partir da segunda parte do livro. A pretensa universalidade do direito sagrado da maternidade foi uma das ferramentas utilizadas nos discursos abolicionistas do Brasil e de Cuba, os quais apelavam para um sentimento de igualdade entre as mães, independentemente de sua cor ou condição jurídica. Como destaca a autora, a evocação do sentimento de emoção transformou-se numa estratégia importante do movimento abolicionista que, a um só tempo, pregava a sacralidade da maternidade e ajudava a forjar um novo código de conduta da elite masculina, que começava a enxergar a mulher escrava de outra forma.

Camillia Cowling demonstra que a sacralidade universal da maternidade foi apreendida de diferentes formas nas sociedades escravistas. Se por um lado, a partir da década de 1870, tal assertiva ganhou força quando a liberdade do ventre ganhou status de lei, por outro lado a pretensa igualdade que a maternidade parecia garantir para as mulheres muitas vezes parecia restringir-se ao campo jurídico, mais especificamente, à luta gradual pela liberdade. Revelando uma vez mais a complexidade dos temas abordados, Camillia Cowling destaca que esses mesmos abolicionistas muitas vezes descriam na feminilidade das mulheres negras (brutalizadas pela escravidão), colocando-se contrários às relações inter-raciais, embora defendessem a manutenção das famílias negras.

Todavia, nesse contexto, o ponto alto do livro reside justamente no exame das estratégias empregadas pelas mulheres negras para lutar, juridicamente, pela liberdade não só de seu ventre, mas de seus filhos. A compreensão que essas mulheres tinham das leis graduais de abolição; o entendimento também compartilhado por elas de que as cidades do Rio de Janeiro e de Havana não eram apenas espaços privilegiados para suas lutas, mas também uma parte importante para a definição do que a liberdade poderia significar; e as redes de solidariedade tecidas por essas mulheres, que muitas vezes extrapolavam os limites urbanos, são algumas das questões trabalhadas pela autora.

Os desdobramentos dessas questões são muitos, a maioria dos quais analisada por Camillia Cowling na última parte de seu livro. As concepções que as mulheres negras desenvolveram sobre liberdade e feminilidade com base na maternidade merecem especial atenção, pois elas permitem, em última instância, redimensionar os conceitos de escravidão e, sobretudo, de liberdade nos anos finais de vigência da instituição escravista das Américas e nos primeiros anos do Pós-abolição. Se é verdade que, assim como aconteceu como Josepha Gonçalves e Ramona Oliva, a luta jurídica pela liberdade de seus filhos não 
teve o desfecho desejado e eles continuaram na condição de cativeiro, os caminhos e lutas trilhados por elas não só criaram outras formas de resistência à escravidão - que por vezes, tiveram outros desfechos -, como ajudaram a pautar práticas de liberdade e de atuação política que ganhariam novos contornos na luta pela cidadania plena alguns anos depois.

O tratamento dado pela autora sobre a luta de mulheres/mães pela liberdade de seus filhos e a forma por meio da qual ela enquadra tais questões naquilo que se convém chamar de "contexto mais amplo" faz que Conceiving Freedom possa ser tomado como uma importante contribuição nos estudos da escravidão urbana, não só por sua perspectiva comparada, mas também por trabalhar num território de fronteira da historiografia clássica, demonstrando que os limites entre o mundo escravista e o mundo da cidadania não podem ser balizados apenas pela declaração formal da abolição da escravidão. A luta começou antes dessas datas oficiais e continuou nos anos seguintes, sobre isso não restam dúvidas. Todavia, o protagonismo desse movimento não se restringiu às ações dos homens que lutaram pela abolição. Ao invés de fechar uma temática, o trabalho de Cowling indica novos caminhos num campo que poderá trazer contribuições promissoras para os estudos da escravidão e da liberdade nas Américas.

Por fim, vale ressaltar que num momento político como o atual, em que tanto se fala, se discute e se experimenta o empoderamento de mulheres negras, o livro de Camillia Cowling é igualmente bem-vindo. Não só por iluminar trajetórias que foram silenciadas ou tratadas como simples anedotas (demonstrando que a luta não é de hoje), mas igualmente por permitir repensar os moldes e os modelos por meio dos quais as histórias e as memórias da escravidão e da luta pela liberdade são construídas.

\section{REFERÊNCIA}

TOMICH, Dale. Pelo prisma da escravidão: trabalho, capital e economia mundial. São Paulo: Edusp, 2011.

\section{NOTA}

${ }^{1}$ Doutora em História Social pela Universidade de São Paulo (USP). Professora Adjunta de História da Escola Superior de Ciências Sociais CPDOC-FGV.

Resenha recebida em 25 de maio de 2016. Aprovada em 27 de maio de 2016. 